\title{
Unable to Inhale in an Historical Square
}

\author{
Damla Atik ${ }^{1}$, Emine Keleş ${ }^{2}$, Gökçen Bayrak ${ }^{1}$
}

\begin{abstract}
Livable and sustainable cities are required to respond space-activity necessities of people as much as to provide satisfaction of users in terms of social and physiological ways. Urban squares definitely attract the attention among urban spaces that having significant place in city fiction and life. It is possible to consider squares which were identified with various names through history as "inhalation yards" of a city. Been shaped by culture, life style and expectations of the society whom they belong; squares have importance to obtain sustainability in developing and growing cities. Edirne as a medium scaled city is located in the north-west part of Turkey; have country borders with Greece and Bulgaria; had been capital city of Ottoman Empire almost a century though has cultural and historical wealth. The most significant square of the city is Cumhuriyet Square and it is located in the historical city center. The square has transferred almost all of its facilities and functions to the Saraçlar Street neighbor on, being precluded by traffic axis at the present time. It is aimed to draw attention on cultural and historical traces of the city by scrutinizing the square in terms of usage and meaning in this study. Data will be obtained by evaluating socio-economic, cultural and physical changes of the city and improving project will be suggested for sustainability and future. It is predicted that this suggestion (or inspiring new projects) will be made actual by further surveys providing contribution of society as well as support of administrators who are claiming similar approaches.
\end{abstract}

Keywords: Urban square, urban sustainability, cultural sustainability, bistorical center, Edirne, Cumburiyet Square, Atatürk Statue

\section{Introduction}

Our surrounding environment must be handled within two dimensions; user and space regarding to social and physical environment. We know that interaction and attraction between people and environment go on in an endless way. The most specific interaction is observed in cities today depending upon population intensity. Migration related to social and economic requirements speeds up urbanization thus population increase is observed in cities. Due to this crowded and multi-functioned spaces, sustainability of cities gain importance against the complexity of both spatial arrangements and daily life. Livable and sustainable cities are required to respond spaceactivity necessities of people as much as to provide satisfaction of users in terms of social and physiological ways. Thus organization of urban open areas and urban spaces become important.

Urban spaces are places defined by buildings but are outer parts of them (Çakmakl1, 1992). They can be classified as boulevards, streets, squares and all outside formations shaped and orientated by building facades (Çakmakl1, 1992). Moreover, (Lynch, 2011) identified the cities and the urban space through five elements: paths, edges, districts, nodes and 
landmarks; relating both on the physical form and the symbolic aspects. Lynch's elements all together provide a complete image of the city: districts are structured with nodes, defined by edges, penetrated by paths, and sprinkled with landmarks; elements regularly overlap and pierced one another. Zeka extracts Colquhoun's (1989) definition of urban space as "social space" and "built space". While built space concentrates on the physical space and its morphology, the way it affects our perceptions, the way it is used and the meanings it can elicit; social space deals with the spatial implications of social institutions according to him (Zeka, 2011). We come through public space within social dimension.

Besides the concerns on public accessibility, public spaces deal mainly with bringing people together. Public spaces are spaces where citizens can gather, linger or wander through and have positive social interactions with friends or strangers, facing differences and learning to understand and tolerate others; in other words, it is where communities regenerate themselves through dialogue, action and reflection together with the variety and diversity of activities (Zeka, 2011). With this approach we find out urban squares definitely attract the attention among urban spaces that have significant place in city fiction and life. A square or plaza is both an area framed by buildings and an area designed to exhibit its buildings to the greatest advantage. (Moughtin, 2003).

Having various terminologies in different societies through history, urban square concept is accepted as an open space for public use. They are the nodes of citizens and the most supportive communication tools for social life. Levy stated the main difference between a public park and a public square as "on a square, citizens are not connected to manifestations of nature, but to the heart of urban culture, history and memory" (Levy, 2011). According to (Lynch, 2011), urban square is the "activity focus" in the center of dense urban areas. Besides, squares are "inhalation yards" of a city we mention. The Cumhuriyet square in Edirne is effeteness as it is used as a passage; as it transferred the facilities that a square should have to Saraçlar Street. This study approaches the square for inhalation and improvement.

\section{Material and Method}

The material (research area) of the study is Cumhuriyet Square of Edirne city as well as the historical city center (historical core). Edirne as a medium scaled border city is located in the north-west part of Turkey (Figure 1); have country borders with Greece and Bulgaria; had been $2^{\text {nd }}$ capital city of Ottoman Empire almost a century; though have cultural and historical wealth.

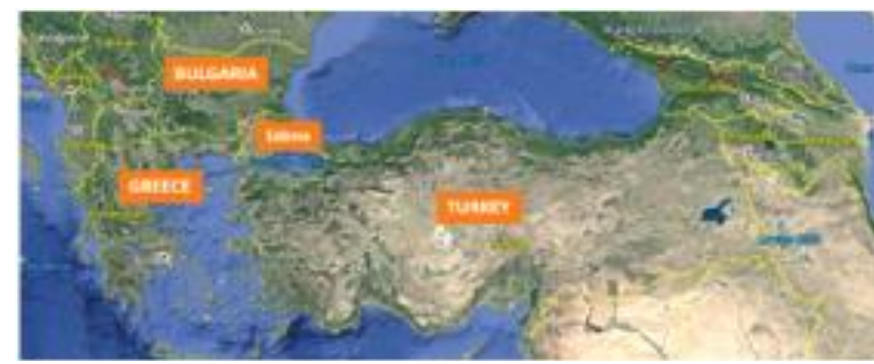

Figure 1. Satellite image of Edirne city location in Turkey 
Mosques, other religious building, social complexes, museums, caravanserais and inns, palace ruins, fountains, rivers and bridges, bazaars, hamams (Turkish bath), martyrs' memorials, civil architecture and monuments are tangible wealth of Edirne besides Kirkpinar Oil Wrestling Games, gastronomy, traditional handicrafts, festivals and belief tourism as intangible values of the city. The city center particularly, have various cultural monuments; especially "The Golden Triangle" whoso corners refer the Selimiye Mosque, Old Mosque and Üç Şerefeli Mosque (Figure 2).

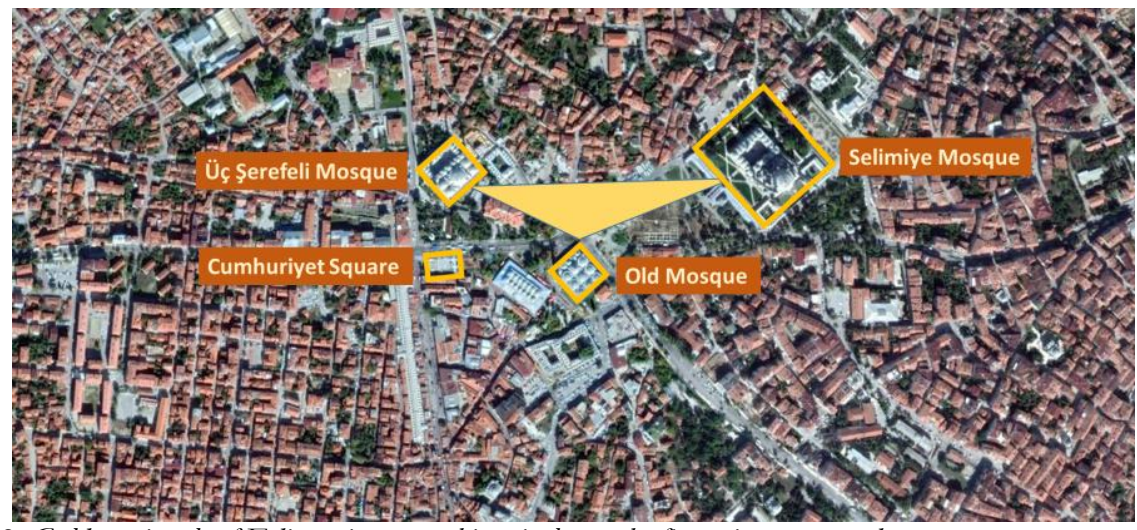

Figure 2. Golden triangle of Edirne city center-historical core the figure is regenerated

The Selimiye Mosque Complex is a masterpiece of the human creative genius of the architect Sinan, the most famous of all Ottoman architects in the 16th century. With its cupola, spatial concept, architectural and technological ensemble and location crowning the cityscape illustrates a significant stage in human history. The Selimiye Mosque Complex includes all the attributes of its Outstanding Universal Value within the property boundary. In view of the importance of the dominant setting of the property and its landmark status, it retains its authenticity in terms of form and design, materials and substance (URL1, 2018). Selimiye Mosque and its Social Complex covers 2.5ha and is surrounded by a buffer zone of 37.5ha. It was included in the Tentative List 25 February 2000 and then accepted UNESCO's World Heritage List. Urban Conservation Plan is the master plan for the historical core of Edirne city, which includes the Mosque Complex and its buffer zone (URL2, 2018). The surrounding buffer zone is designed to cover the surrounding historic context which are also subject to this study.

The most significant and oldest square of the city is Cumhuriyet Square and it is located in the historical city center; on Talatpaşa Street (Figure 3). The Saraçlar Street connected to the edge of the square is the social and commercial center of the city. The 700 meters long street has linear form parallel to the Ali Pasha Bazaar and had pedestrianization applications beginning with year 2008; totally closed to vehicle traffic at the present time. The square is generally used for formal celebrations and a passage area. Thus it transferred facilities to the Saraçlar Street particularly being precluded by traffic axis at the present time. 


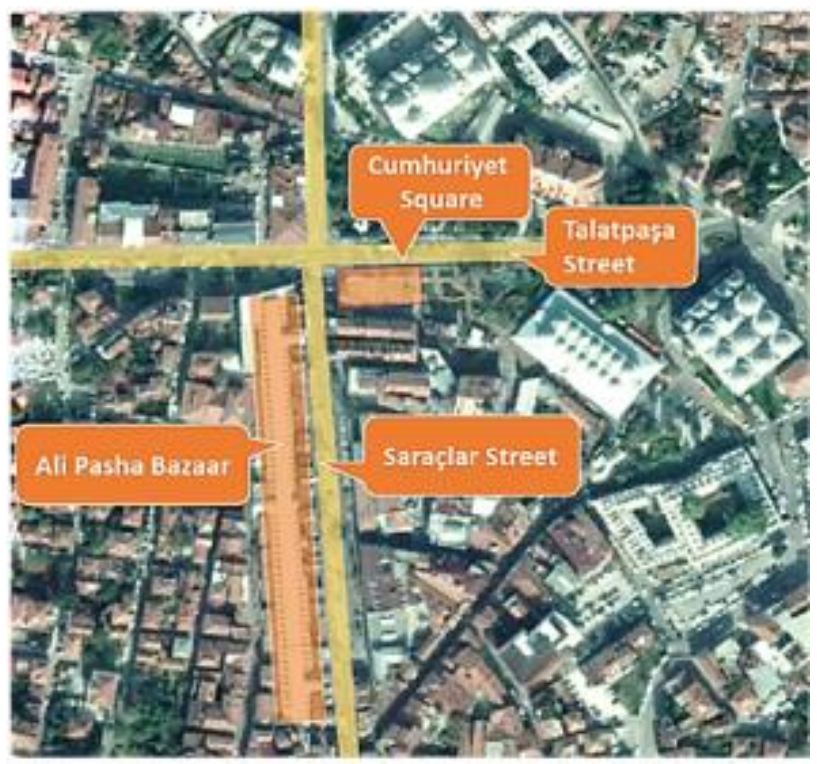

Figure 3. Talatpassa and Saraçlar Str.-Cumburiyet Square

Urban squares are an opportunity for people to express themselves in terms of culture, idea and life style; identity in general. Because we know that urban squares were been shaped by usage, life styles, expectations of the society, meaning, management approach and etc., it is possible to claim that there is no simple formula for a successful square, and every square is unique. For example, busy metropolitan traffic junctions such as New York's Times Square are squares in name only and should be designed bearing in mind their primary function, the efficient movement of city traffic (Moughtin, 2003). Or the traditional European town squares are surrounded by an almost continuous wall of buildings, with small entrances and exits leading in and out, creating the feeling of an outdoor salon or ballroom (Lennard \& Lennard, 2007). Most of the surrounding buildings are complemented by important civic and religious edifices that are frequently, though not always, part of the contiguous urban fabric of the square, and emphasize its significance as the most important place in the city. (Lennard \& Lennard, 2007). In another words, European squares assume formal representations and focal point of urban life (Oktay, 2007). Oktay extracts Cerasi's estimation as public spaces of Ottoman cities have independent formations and focal point of urban life is bazaar and mosque. The square phenomenon is translated into Turkish as "space, open area, yard" but even so it has the description of unstructured institutive area (Oktay, 2007).

Reflecting the cultural components, it can be said that squares have importance to obtain sustainability both from past to today and from today to future in developing and growing cities such as Edirne. Urban squares are evaluated and Table 1 is prepared developing from (Akkar Ercan, 2007) (Lennard \& Lennard, 2007) (Zeka, 2011) (Moughtin, 2003) inferring the roles of squares in terms of physical, socio-cultural, economical, psychological, political, ecologic, symbolic. 
Table 1. Roles of urban squares

PHYSICAL
Form and Size
Zucker suggested the forms as the closed square where the space is self-contained; the dominated square where the
space is directed towards the main building; the nuclear square where space is formed around a center; grouped
squares where spatial units are combined to form larger compositions; and the amorphous square where space is
unlimited. square's form is influenced by the surrounding environment on the other hand. The enclosure of space is
the purest expression of a sense of place, the center. Surrounding buildings affect the degree of enclosure. Location of
a square directly influences the accessibility regarding whether it is located within a close distance to main pedestrian
and vehicular traffic routes and transportation nodes. Size should be determined according to the location and
activities nearby. Activity in a square is important for its vitality. Squares include tools and facilities in order to serve
for the daily needs of people. Urban equipment and pavement materials are important.

\section{SOCIO-CULTURAL}

Dialog and Sociability

Education

Squares are open to everyone; they serve social interaction. A square is a place for dialogue and discussion, meetings and greetings, for shared experiences and forming bonds. People exchange stories about their lives and experiences; details about family, work, state of health, plans and hopes. This significant conversation and dialogue the ultimate expression of life in the city creates community. Thus square fosters sociability. Sociability is the basis of many of the activities and events that make social life on the square joyful and meaningful. Especially for children, square offers an important learning environment. Children and youth learn the behavior, the attitudes, the skills that transform them into competent, responsible adults capable of, and interested in participating in the life of their community.

\section{ECONOMICAL}

\begin{tabular}{|l|l|l|}
\hline Market & Commercial Activities & Transportation \\
\hline
\end{tabular}

Markets have been one of the essential elements of the public squares through history. Even today the market is the most powerful mechanism for generating social life and economic activity on the square, more powerful than any other activity. Squares are primary locations of commerce and economic activities. They are also the intersection, gathering and waiting points for both the pedestrian and vehicle traffic.

\section{PSYCHOLOGICAL}

\begin{tabular}{|l|l|l|}
\hline Mental health & Comfort & Meaning \\
\hline
\end{tabular}

Considering the surrounding buildings and the dome of the sky; squares demand an emotional and cerebral response. The interaction of people in a square give pleasure to each other, not to enhance one's status or position, but to increase each other's sense of well-being. The status of each, their social or economic position, knowledge or fame is not as important as personal qualities, graciousness, cordiality and charm. Children get a sense of the pleasure some experience in being with, meeting and talking to each other. Comfort is related to both physical materials-equipment and spiritual. Meaning has diversity for each individual's experience, memory and cognitive background.

\section{POLITICAL}

\section{Democratic dialogue}

Ceremonies and meetings

\section{Participation}

They provide a place for political participation and public discussions. Sociability makes for more democratic relations. The great diversity of users, the varied viewpoints and opinions that come together on the square, combined with the presence of city hall mean that civic issues are often vehemently debated on the square. In Greece, Italy and Spain it is most frequently the men who gather just before lunch or in the evening to discuss the actions of a city council member, plans for a new building, the threatened strike of factory workers or proposals to resolve an ecologica problem.

\section{ECOLOGIC}

\section{Landscape}

Well-being

\section{Aesthetic}

The vegetation inside or around the squares can ameliorate an unfavorable micro-climate; increase air turbulence, filter dust particles, direct cooling down and cleansing breezes. Thus, they make contribution to the creation of a healthy environment. Together with the ecological roles, squares contribute to the mental health and wellbeing of the people the people. Activity in a square is important for its vitality and, therefore, also for its visual attraction. They improve and enhance the aesthetic quality of the city; work of arts, water usage, attractive focal elements.

\section{SYMBOLIC}

\section{Identity}

\section{Usage and meaning}

\section{Image}

A square is the essence of a city, epitomizing the community's heritage and symbolizing its identity; fostering the cooperative, entrepreneurial, cultural, and democratically organized urban civilization. They can give identity to the places; besides they affect minds and senses of people, and lead influence. The public spaces used for religious purposes are the prominent examples. Therefore, public spaces become symbols for a group of people or a society, since they represent cultural, historical, religious or other social and political values for them. Symbolic roles of public spaces, are 'culture' and 'history'. 
Evaluating the squares with their characteristics through literature review, the Cumhuriyet Square is analyzed; besides, site survey, photograph archives shared on social media are used. The data such as population and socio-economic statistics belonging to Edirne are obtained from web sites of governmental agencies in this study.

\section{Findings}

There had been a garden named "Darülfunun Bahçesi" in the area of the square in 1930's (Figure 4). Macedonian Tower is seen on the left side while Üç Şerefeli Mosque is on the right in Figure 4. At 23 April 1931 (April 23 is celebrated as National Sovereignty and Children's Day which is presented by Mustafa Kemal Atatürk for Turkish Republic and the whole world as well) an Atatürk Statue sculptured by Kenan Ali Yontunç is located on some part of this garden and a square concept has been shaped (Figure 5). The rectangular shaped square is surrounded by Talatpaşa Street on the north, Saraçlar Street on the west, Ugur Mumcu Park on the east and Dar-ül Eytam Bazaar on the south. The square is mostly mentioned as "Atatürk Statue" or "Atatürk Square". National and local special days are celebrated here; ceremonies are organized; wreaths are laid; stand in silence is made and marching bands perform. In addition, this square can be said as formal - ceremony square. The place of the statue is relocated towards east in order to enlarge the square; pavements renewed in various time periods as a result the square is elevated; water and sitting elements are replaced and removed by time since 1970's.

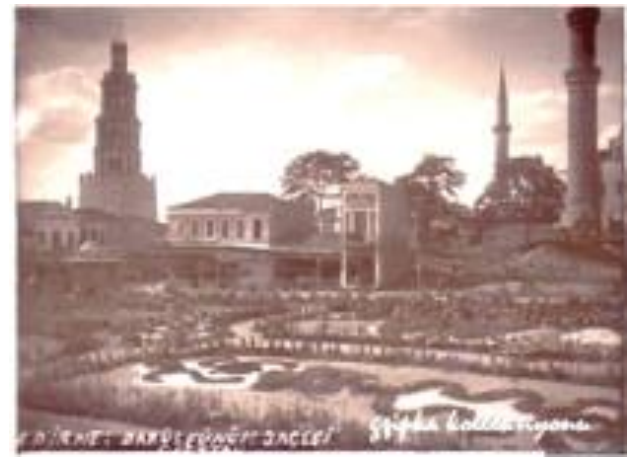

Figure 4. Darülfunun Babcesi (Garden) (URL3, 2018)

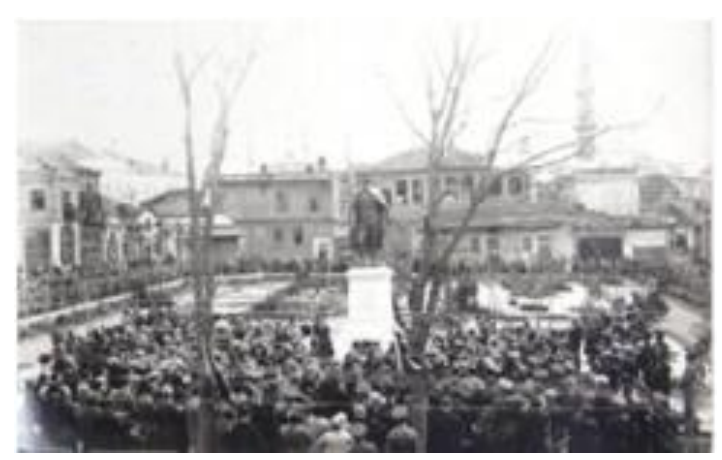

Figure 5. Opening ceremony of Atatürk statue (URL4, 2018)

The square area is observed as three parts today (shown in Figure 6 as 1-2-3). The first part (approx. $150 \mathrm{~m}^{2}$ ) is like a niche attached to Saraçlar Street after it has been pedestrianized. This part is used for sitting place and for some special vehicles parking area unfortunately. The second part can be 


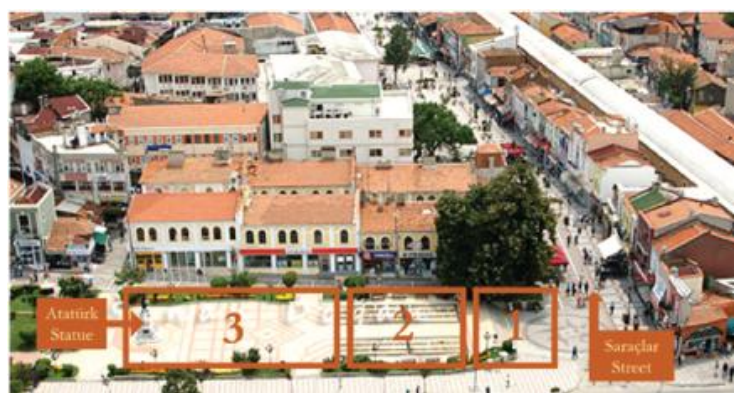

Figure 6. The parts of the square (Photo by Sinan Doğan) (URL5, 2018)

number three in Figure 6 , is $400 \mathrm{~m} 2$ and is tiled by different covering; the statue is centered (eyeshot of Atatürk is towards west side-Saraçlar Street); flagstaffs are located on the south part. The arrangement change observed in the square is shown in Table 2.

Table 2. The arrangement changes of Cumhuriyet Square

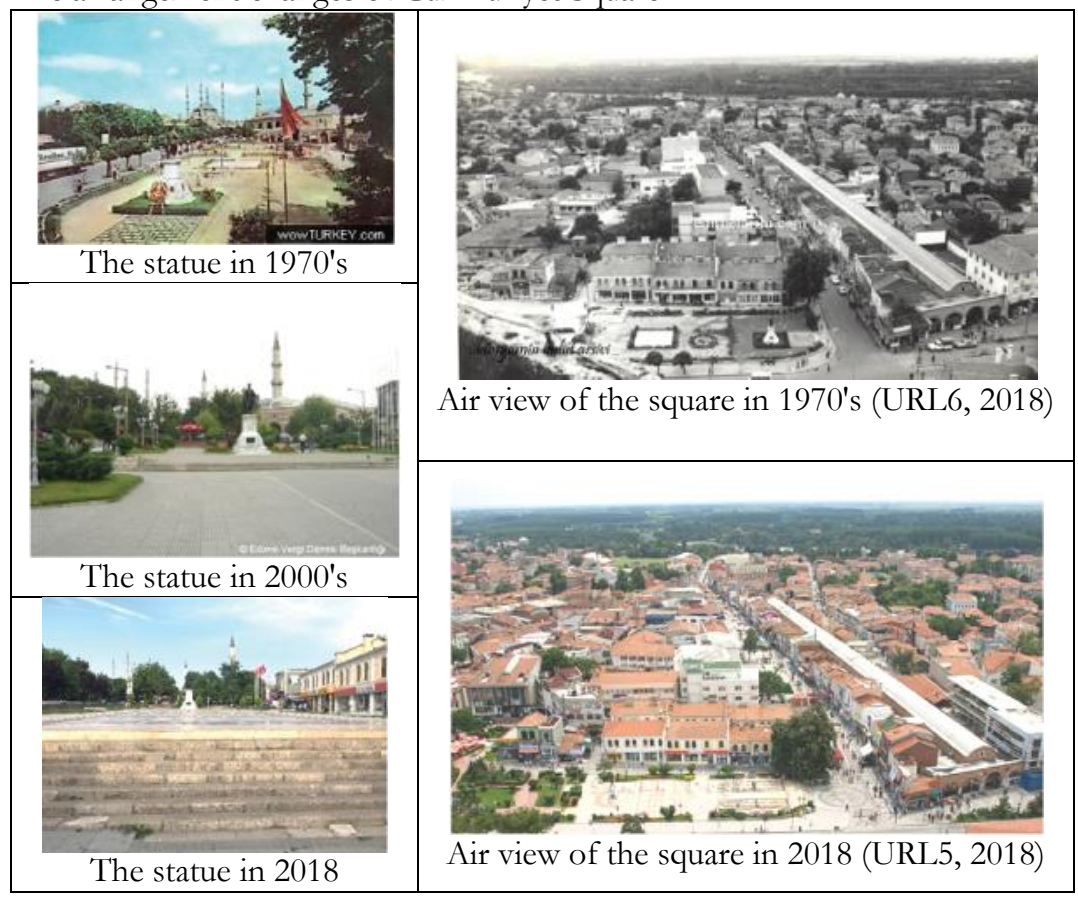

\section{Discussion}

The square has changed by time ordinarily depending on socio-economic and socio-cultural alterations as a result of urbanization besides the city has also experienced. Demographic and socio-economic data indicate that Edirne is a growing city when we analyze it in terms of production, enterprises, education, health, tourism and culture.

Edirne was an important agricultural center for centuries. Wars and chaos in Balkans and Thrace lasted until proclamation of the republic, caused large-scale population 
movements affecting the socio-economic structure of Edirne. After 1923 agriculture began to recover and structural change occurred with the proliferation of tractor in the 1950's. Edirne had an agriculture-based economy until 1969. After than medium and large-scale factories began to be established. Extensity of domestic and foreign transportation facilities for its location, being so close to an industrial and commercial metropolis like Istanbul, Edirne attracted the attention of major industry groups particularly enterprises engaged in the textile began to develop after the 1990's. Wheat, sunflower and rice are cultivated at the large part of the broad and fertile plains. The most important sector in the province is food industry processing of agricultural products such as rice, flour, oil, milk and milk products...etc. besides tourism (URL7, 2018). The effects of urbanization can be seen in Table 3 which shows urban and rural population of the city as well as annual population growth rate. Rural population was dominant regarding to production and agricultural society before 1960's. The effects of World War II can also be seen in 1945's population data. After 1960, the urban movement can be seen by years: as rural population decreases, urban population increases thus, urban culture began to develop, production type began to change and economic structure began to transform. Border gates of Kapikule and Pazarkule particularly provide frequent passages between both Greece and Bulgaria. Foreign and domestic tourists like to visit Edirne because of its historical monuments, local foods, shopping facilities and recreational river side activities on special days, holidays or weekends. All these keep city's economy alive.

Table 3. Population indicators of Edirne city by years (URL8, 2018)

\begin{tabular}{|c|c|c|c|c|c|c|}
\hline \multirow{2}{*}{ Year } & \multirow{2}{*}{ Total } & \multirow{2}{*}{ Urban Population } & \multirow{2}{*}{ Rural Population } & \multicolumn{3}{|c|}{ Annual population growth rate \% } \\
\cline { 5 - 7 } & & & & Total & Urban & Rural \\
\hline 1927 & 150.889 & 48.517 & 102.372 & & & \\
\hline 1935 & 184.840 & 55.812 & 129.028 & 25,37 & 17,51 & 28,93 \\
\hline 1940 & 251.373 & 70.942 & 180.431 & 61,49 & 47,97 & 67,06 \\
\hline 1945 & 198.271 & 52.463 & 145.808 & $-47,46$ & $-60,35$ & $-42,61$ \\
\hline 1950 & 221.268 & 56.354 & 164.914 & 21,95 & 14,31 & 24,63 \\
\hline 1960 & 276.479 & 86.542 & 189.937 & 18,39 & 32,63 & 12,23 \\
\hline 1970 & 316.425 & 119.978 & 196.447 & 8,52 & 32,13 & $-4,65$ \\
\hline 1980 & 363.286 & 153.236 & 210.050 & 12,82 & 24,17 & 4,93 \\
\hline 1990 & 404.599 & 210.421 & 194.178 & 7,54 & 32,78 & $-16,64$ \\
\hline 2000 & 402.606 & 230.908 & 171.698 & $-0,49$ & 9,29 & $-12,30$ \\
\hline 2011 & 399.316 & 272.294 & 127.022 & 22,51 & 38,84 & $-11,63$ \\
\hline
\end{tabular}

Citizens of Edirne are foresighted, participant and democratic people; both men and women take place in social and career life. Most of them have roots in West Thrace as they are migrants. Education level is high besides, Trakya University opportunity is provided both Turkish and foreign students. They increase the demographic, social, cultural and economic value of the city with other appointed government officers. It can be said that Edirne city allow immigrants. Since the first population census of Turkey in 1927 up to today, the numerical data for Edirne is given in Table 4. 
Table 4. General census of Edirne province (URL9, 2018) (URL10, 2018)

\begin{tabular}{|c|c|c|c|c|c|c|c|c|c|c|}
\hline \multicolumn{10}{|c|}{ Population Census of Edirne } \\
\hline 2017 & 2012 & 2007 & 2000 & $\mathbf{1 9 9 0}$ & $\mathbf{1 9 8 5}$ & $\mathbf{1 9 8 0}$ & $\mathbf{1 9 7 5}$ & $\mathbf{1 9 7 0}$ & $\mathbf{1 9 6 5}$ & $\mathbf{1 9 2 7}$ \\
\hline 406.855 & 399.703 & 396.462 & 402.606 & 404.599 & 389.638 & 363.286 & 340.732 & 316.425 & 303.234 & 150.840 \\
\hline \multicolumn{8}{|c|}{ Population Census of Edirne Central District } \\
\hline 2017 & $\mathbf{2 0 1 2}$ & $\mathbf{2 0 0 7}$ & $\mathbf{2 0 0 0}$ & $\mathbf{1 9 9 0}$ & $\mathbf{1 9 8 5}$ & $\mathbf{1 9 8 0}$ & $\mathbf{1 9 7 5}$ & $\mathbf{1 9 7 0}$ & $\mathbf{1 9 6 5}$ & $\mathbf{1 9 2 7}$ \\
\hline 178.910 & 162.161 & 150.717 & 140.830 & 124.361 & 120.663 & 105.503 & 94.449 & 84.531 & 78.161 & - \\
\hline
\end{tabular}

Besides demographic and socio-economic structure of Edirne, historical and sociocultural background of it, is another vital matter. Restricting the monuments and cultural-historical values within this study, the prominent ones surrounding the square is shown in Table 5.

Maybe not the Cumhuriyet Square itself but the historical core and golden triangle have been subject to many suggestions by papers, competitions, etudes and local workshops; particularly the relationship between pedestrians and vehicles, as an important component of urban design. For example, a touristic pedestrian area was suggested for Selimiye Mosque and around in 1968 by Yurdanur Sepkin (Figure 7) or relocation of roads to underground suggestion was made by Behruz Çinici (Figure 8) in 1988 (Erten, 2016). While getting to Selimiye Mosque by vehicle came to the forefront until 1950's; pedestrianization projects became popular after than by 1960's. Finally, after the Ministry of Culture and Tourism has decided to nominate the Selimiye Mosque for the UNESCO World Heritage List in 2010, a national urban design project competition had to be announced inescapably by the Edirne Municipality (National Urban Design Project Competition of Edirne Selimiye Mosque and Surrounding).

Table 5. Cultural and historical values around Cumhuriyet Square

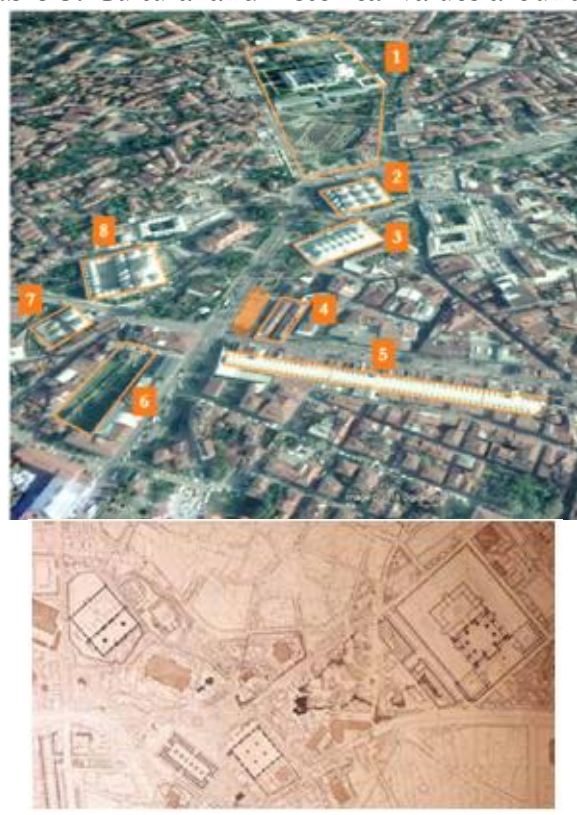

Figure 7. Sepkin's suggestion (Erten, 2016)
1 THE SELIMIYE MOSQUE COMPLEX

2 THE OLD MOSQUE

3 BEDESTEN BAZAAR

4 DAR-ÜL EYTAM BAZAAR

5 ALIPAŞA (ALI PASHA) BAZAAR

6 MACEDONIAN TOWER

7 SOKOLLU HAMAMI

8 THE ÜÇ SEREFELI MOSQUE

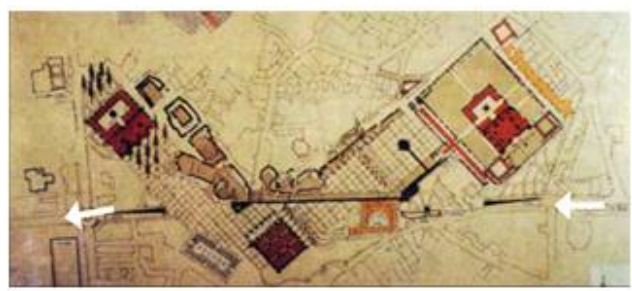

Figure 8. Cinici's suggestion (Erten, 2016) 
The Selimiye Mosque was predominantly desired to be the historical, architectural, sociological and ethnological focal point in modernist planning processes thus, roads and streets were designed according to the mosque (Onur, 1990). After establishing Talatpaşa Street (Londra Asphalt) in 1934, the city morphology began to change and by 1950's the historical core was divided into two parts between Selimiye Mosque and Old Mosque (Onur, 1990). Thus, pedestrian-vehicle transportation always became the main issue and will be. It is impossible to deny a centralized square supported by pedestrianization at the end of Alipasha Bazaar and in front of monuments 6-7-8 with an opening perspective to the Selimiye Mosque while analyzing the map in Table 5. As a huge expropriation and pedestrianization work requires to be made, this centralized square idea seems to be postponed. However, administrators and academicians agree with the idea of more useful and qualified square for citizens of Edirne (URL11, 2018) (URL12, 2018) (URL13, 2018) (URL14, 2018). The common point is that a proper square is desired in Edirne city for its users.

\section{Conclusion and Results}

There may be four alternatives for a square arrangement, we claim (Figure 9). First and the most utopist one is a) an enlarged and centralized square towards to west and on pedestrianized streets. The second one is b) relocating the square in the middle of Saraçlar Street; as difficult as the first suggestion. The third approach may be c) to enlarge the square towards the southeast direction till Bedesten Bazaar and connect with the other pedestrian areas in that city block. And finally the fourth suggestion is the "short term rehabilitation" as shown in Table 6 related to the findings and implications. It seems more possible to rehabilitate the Cumhuriyet Square rather than to make it an enlarged and centralized square due to the difficulty (at least) in a short term.

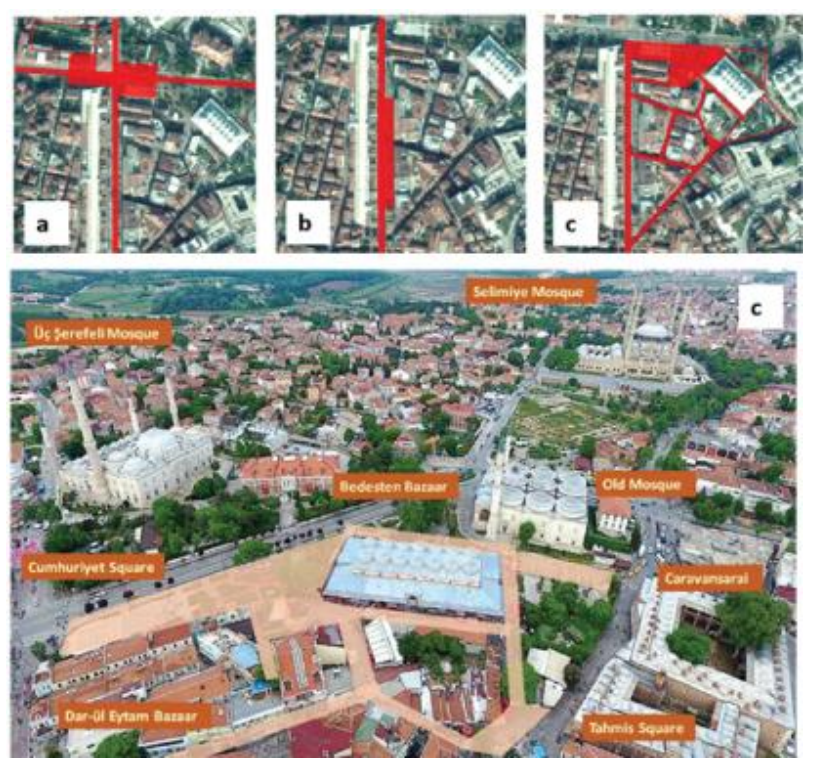

Figure 9. Suggestions for Edirne Cumburiyet Square (Photo by: Salih Baran) (URL15, 2018) 
In contemporary cities, squares become increasingly necessary as gradually places of flow and crossing points tend to surpass the places of rest, which are also fundamentally places where mankind can stop and think about the city and its personal identity and destiny. One could of course counteract that urban squares are not the only places to present the characteristics (Levy, 2011). It is aimed to draw attention on cultural and historical traces of the city by scrutinizing the square through roles, usage and meaning in this study. User needs and expectations take role in forming spaces and space usage affect people. Space design considering user aspects and needs as well as feedback become important in terms of sustainability. It is observed that Cumhuriyet Square is about to fail to gain it and as Oktay mentioned "A square must be supported by historical, social, cultural and aesthetic characteristics considering that it contributes urban sustainability linking up the past" (Oktay, 2007). Data will be obtained by evaluating socio-economic, cultural and physical changes of the city and improving project will be suggested for sustainability and future. It is predicted that this suggestion (or inspiring new projects) will be made actual by further surveys providing contribution of society as well as support of administrators who are claiming similar approaches.

Table 6. Findings and suggestions for Edirne Cumhuriyet Square

\section{EDIRNE CUMHURIYET SQUARE}

\begin{tabular}{|c|c|c|}
\hline ROLES & FINDINGS & SUGGESTIONS \\
\hline \multicolumn{3}{|l|}{ PHYSICAL } \\
\hline Form and Size & $\begin{array}{l}\text { The square is rectangular and } 850 \mathrm{~m} 2 \text {. Form, } \\
\text { size and scale of t it is useful in average. Its } \\
\text { typology doesn't fit to any of Zucker's } \\
\text { classification properly but it can be } \\
\text { interpreted as closed due to its surrounding } \\
\text { linear axis. }\end{array}$ & $\begin{array}{l}\text { To become a mainly closed square, it needs } \\
\text { more specific physical identification; may be } \\
\text { supplied by green pattern to obtain } \\
\text { "enclosure" other than that building frame is } \\
\text { not mandatory. }\end{array}$ \\
\hline $\begin{array}{l}\text { Location and } \\
\text { Accessibility }\end{array}$ & $\begin{array}{l}\text { Being at the corner and intersection of linear } \\
\text { axis of both vehicle and pedestrian access, } \\
\text { location seems to have no problem after all it } \\
\text { can't be changed unless pedestrianization of } \\
\text { Talatpaşa Street. }\end{array}$ & $\begin{array}{l}\text { But it must be mentioned that the stairs } \\
\text { prevent accessibility in terms of universal } \\
\text { design. A ramp can be organized beginning } \\
\text { from statue level down to Saraçlar street on } \\
\text { the east side. }\end{array}$ \\
\hline $\begin{array}{l}\text { Urban equipment and } \\
\text { Material }\end{array}$ & $\begin{array}{l}\text { There exist no sitting elements for users in } \\
\text { order to stop over, have a sit, relax and knit } \\
\text { up with other people. Besides, the tiling is } \\
\text { changed from time to time unqualified. }\end{array}$ & $\begin{array}{l}\text { Urban equipment such as sitting furniture, } \\
\text { dustbins and lighting should be supplied as } \\
\text { well as tiling materials be improved. }\end{array}$ \\
\hline \multicolumn{3}{|c|}{ SOCIO-CULTURAL } \\
\hline $\begin{array}{l}\text { Socialization and } \\
\text { Activities }\end{array}$ & $\begin{array}{l}\text { Activities such as street concerts, start point } \\
\text { of some sport activities or festivals are hosted } \\
\text { by Saraçlar Street. }\end{array}$ & $\begin{array}{l}\text { An opportunity should be provided for all } \\
\text { ages of users within various functional } \\
\text { activities; both day and night. }\end{array}$ \\
\hline Dialog and Sociability & $\begin{array}{l}\text { Lack of equipment restricts social interactions } \\
\text { as well. }\end{array}$ & $\begin{array}{l}\text { This can be solved by supporting physical } \\
\text { equipment and social activity opportunities. }\end{array}$ \\
\hline Education & Children prefer to have time on dry dock. & $\begin{array}{l}\text { Visual and educational data plates can be } \\
\text { placed besides, physical equipment and social } \\
\text { activity opportunities for them to observe } \\
\text { and experience. }\end{array}$ \\
\hline \multicolumn{3}{|l|}{ ECONOMICAL } \\
\hline Market & $\begin{array}{l}\text { Local markets, handmade sales and charity } \\
\text { sale activities take place in another parts of } \\
\text { the city. }\end{array}$ & $\begin{array}{l}\text { There has no need for an permanent market } \\
\text { here; they may be organized on some special } \\
\text { days occasionally. }\end{array}$ \\
\hline Commercial Activities & $\begin{array}{l}\text { Commercial activities are hosted by Saraçlar } \\
\text { Street. }\end{array}$ & $\begin{array}{l}\text { There has no need for commercial activities } \\
\text { here as this can't compete with Saraçlar street }\end{array}$ \\
\hline
\end{tabular}




\begin{tabular}{|c|c|c|}
\hline Transportation & $\begin{array}{l}\text { The square is at the intersection of pedestrian } \\
\text { and vehicle traffic as a distribution and } \\
\text { transition point. }\end{array}$ & $\begin{array}{l}\text { The square needs to get rid of transition only; } \\
\text { it also should keep users inside. Urban } \\
\text { equipment and landscape design should be } \\
\text { provided. }\end{array}$ \\
\hline \multicolumn{3}{|l|}{ PSYCHOLOGICAL } \\
\hline Mental health & $\begin{array}{l}\text { Despite insufficient usage of green materials; } \\
\text { open air opportunity provide inhalation. }\end{array}$ & $\begin{array}{l}\text { Music, color and scent should rehabilitate } \\
\text { mental health of users. }\end{array}$ \\
\hline Comfort & The square is lack of comfort. & $\begin{array}{l}\text { Shade trees and resting elements should be } \\
\text { provided. }\end{array}$ \\
\hline Meaning & $\begin{array}{l}\text { Atatürk statue is the meaning of the square } \\
\text { for citizens of Edirne. }\end{array}$ & $\begin{array}{l}\text { Visions are required to gain users new } \\
\text { memories and positive images besides } \\
\text { Atatürk statue. They should feel belonging as } \\
\text { a vital necessity. }\end{array}$ \\
\hline \multicolumn{3}{|l|}{ POLITICAL } \\
\hline Democratic dialogue & $\begin{array}{l}\text { The square has no politic role exactly except } \\
\text { ceremonies. Dialogs are made in cafes. }\end{array}$ & $\begin{array}{l}\text { This can be solved by supporting physical } \\
\text { equipment and social activity opportunities } \\
\text { thus, users can discuss. }\end{array}$ \\
\hline $\begin{array}{l}\text { Ceremonies and } \\
\text { meetings }\end{array}$ & $\begin{array}{l}\text { Wreaths are laid; stand in silence is made and } \\
\text { marching bands perform in the square. } \\
\text { Meetings are held in another place. }\end{array}$ & $\begin{array}{l}\text { This mission is the heart and the soul of the } \\
\text { city and ideology. There has no need to be } \\
\text { changed. }\end{array}$ \\
\hline Participation & $\begin{array}{l}\text { The square can no succeed to be the center } \\
\text { of social and urban life. }\end{array}$ & The more equipment, the more participant. \\
\hline \multicolumn{3}{|l|}{ ECOLOGIC } \\
\hline Landscape & $\begin{array}{l}\text { Landscape design is not established properly } \\
\text { beyond a few planting and dry dock. }\end{array}$ & $\begin{array}{l}\text { A proper lighting, water elements, planting } \\
\text { plots should be designed. Talatpaşa side of } \\
\text { the square may be planted along the road as a } \\
\text { border. }\end{array}$ \\
\hline Well-being & $\begin{array}{l}\text { Large and open space provide inhalation } \\
\text { unless the exhaust resources. }\end{array}$ & $\begin{array}{l}\text { Voice of water, smell of flowers visual } \\
\text { perception of different colors should be } \\
\text { contributive. }\end{array}$ \\
\hline Aesthetic & $\begin{array}{l}\text { The incompatible tiling usage harms } \\
\text { aesthetic. The statue and a few landscape } \\
\text { arrangements are incapable to fulfill this } \\
\text { requirement. }\end{array}$ & $\begin{array}{l}\text { Visual pleasure should be provided by using } \\
\text { landscape and art elements. }\end{array}$ \\
\hline \multicolumn{3}{|l|}{ SYMBOLIC } \\
\hline Identity & $\begin{array}{l}\text { The identity of the square is the Atatürk } \\
\text { statue. The dry dock also may influence the } \\
\text { bearing in mind. }\end{array}$ & $\begin{array}{l}\text { Spending time in the square (resting-sitting- } \\
\text { observing) should increase visual perception } \\
\text { of surrounding atmosphere which are the } \\
\text { identity of the city. }\end{array}$ \\
\hline Usage and meaning & $\begin{array}{l}\text { The square is mainly used as a passage. Thus, } \\
\text { users tend to ignore it and usage-meaning of } \\
\text { the square is frustrated. }\end{array}$ & $\begin{array}{l}\text { Users should be motivated in order to feel } \\
\text { and think about the city as well as the square. } \\
\text { Urban spaces are vital to have connection } \\
\text { with the past and to gain sustainability. This } \\
\text { will support social memory. }\end{array}$ \\
\hline Image & The image of the square is the Atatürk statue. & $\begin{array}{l}\text { Visual pleasure should be provided by using } \\
\text { landscape and art elements. Spending time in } \\
\text { the square should increase perception of } \\
\text { surrounding image elements and include it } \\
\text { into this image within genius loci. }\end{array}$ \\
\hline
\end{tabular}

\section{References}

Akkar Ercan, Z. M. (2007). Public spaces of post-industrial cities and their changing roles. METU JFA(24:1), 115-137.

Çakmaklı, D. (1992). Bina-kentsel cevre iliskisi. YTÜ Mimarlık fakültesi yayını no:MF-Mim92.031.

Erten, S. (2016). Bir kentsel tasarım yarışmasının süreç analizi: Edirne/Selimiye örneği ve tarihi merkezde araç yolu tartışması. planlama, 26(1), pp. 20-31. doi:10.5505/planlama.2016.53824 
Lennard, S. H., \& Lennard, H. L. (2007). Social life on the square. In Genius of the european square (pp. 17-27). Retrieved from https://www.livablecities.org/articles/genius-european-square

Levy, B. (2011). Urban square as the place of history, memory, identity. International symposium memory of the city, (pp. 156-173). Belgrade. Retrieved from http://www.kulturklammer.org/docs/SECANJE_GRADA--MEMORY_OF_THE_CITY.pdf

Lynch, K. (2011). Kent imgesi (3 ed.). (İ. Başaran, Trans.) Türkiye iș bankası kültür yayınları.

Moughtin, C. (2003). The square or plaza. In Urban design: street and square (pp. 87-125).

Oktay, D. (2007). Kentsel Kimlik ve Canlılık Bağlamında Meydanlar: KUZEY KIBRIS’TA BİR MEYDANA BAKIŞ. Mimarlke(334). Retrieved from http://www.mimarlikdergisi.com/index.cfm?sayfa $=$ mimarlik\&DergiSayi $=52 \& R e c I D=1288$

Onur, O. (1990). Edirne kent planının geçirdiği evrelere kısa bir bakış. mimarlkk(90/2), pp. 64-67. Retrieved from dergi.mo.org.tr/dergiler/4/296/4188.pdf

URL1. (2018). Retrieved May 2018, from https://whc.unesco.org/en/list/1366

URL10. (2018). bttp:// wmw.trakyanet.com/istatistikler/nufus/yillara-gore-nufus/yillara-gore-nufus-edirne.btml. Retrieved June 2018

URL11. (2018). Retrieved from http://www.edirnehaber.org/haber/19742/cumhuriyet-meydani-projesindefikir-birligi.html.

URL12. (2018). Retrieved from http://www.milliyet.com.tr/edirne-ye-yapilmasi-planlanan-cumhuriyetedirne-yerelhaber-1670329/.

URL13. (2018). Retrieved from http://www.hudutgazetesi.com/haber/38636/selimiye-manzarali-fatih.html.

URL14. (2018). Retrieved from http://www.hurriyet.com.tr/edirnede-altin-ucgeniin-trafige-kapatilsin-t40498341 .

URL15. (2018). Retrieved from https://www.aa.com.tr/tr/turkiye/vakif-sehir-edirne-/1139796.

URL2. (2018, June). Retrieved from whc.unesco.org/document/152488

URL3. (2018). mnw.edirnetaribi.com/ataturk-meydani-boyleydi.html. Retrieved May 2018

URL4. (2018). wnw.edirnetaribi.com/23-nisan-1931-edirnede-ataturk-anitinin-acilis-toreni.btml. Retrieved May 2018

URL5. (2018). wnw.flickr.com/photos/sinandogan/31791885430. Retrieved June 2018

URL6. (2018). wnw.edirnetaribi.com/edirne-osmanli-eserleri-1970-1971-bunyamin-bulut-arsivi.btml/ edirne-ali-p_-kapalicarsisixxxi-161970s-1. Retrieved April 2018

URL7. (2018). Retrieved June 2018, from http://etso.org.tr/en/kategori/edirne-industry-and-trade.

URL8. (2018). mww.edirne.gov.tr/ortak_icerik/edime/d\%C3\%B6k\%C3\%BCmanlar/planlama/11122012/12demografi.pdf. Retrieved June 2018

URL9. (2018). www.trakyanet.com/istatistikler/nufus/yillara-gore-nufus.btml\# ldirne. Retrieved June 2018

Zeka, B. (2011). The humanistic meaning of urban squares:. Master thesis School of natural and applied sciences of METU. 